\title{
Exemptions for Religious Groups and the Problem of Internal Dissent
}

\author{
Paul Billingham (Christ Church, University of Oxford) \\ paul.billingham@chch.ox.ac.uk
}

\begin{abstract}
Liberal justifications of exemptions for religious groups appeal to the rights or interests of individuals. Individuals' interests in freedom of religion and association are said to be served through religious groups being granted a level of autonomy from state control, which includes their enjoying exemptions from certain otherwise applicable laws. All such justifications face a significant problem, however, which is that religious groups invariably contain dissenters, who object to the group's decisions, policies, or current exercise of an exemption. It is unclear how these internal dissenters' interests are served by the group being granted exemptions. This chapter explores, and seeks to resolve, this problem. I show that three standard liberal responses-appealing to the religious groups' own decision-making procedures, to implied consent, and to exit rights-contain important insights, but do not provide a satisfactory solution. I then argue that liberal political theory nonetheless has the resources to justify exemptions for religious groups in the face of internal dissent, by highlighting the way in which dissenters' own interest in freedom of religion can be protected and promoted through religious group autonomy. This enables liberal theorists to justify internally contested exemptions for religious groups.
\end{abstract}

\section{Introduction}

Religious groups often seek a level of autonomy from state control. They desire an area in which they exercise self-governance, allowing them to structure their collective life according to their own religious and ethical precepts, without interference from the state. As Douglas Laycock puts it, 'a church autonomy claim is a claim to autonomous management of a religious organization's internal affairs'. ${ }^{1}$

This kind of religious group autonomy is manifested in various ways within liberal societies, including through groups' being able to de-

${ }^{1}$ Douglas Laycock, 'Church Autonomy Revisited' (2009) 7 Georgetown Journal of Law and Public Policy 253, 254. 
fine their doctrines and beliefs, choose their members and leaders, set standards of conduct, and discipline those who violate those standards, all free from state interference. States are also hesitant to adjudicate property disputes that can only be resolved through judgements of religious doctrines, or to assess torts that would challenge the validity of religious rituals and practices. While the precise ways that these various issues are handled varies between different jurisdictions, all liberal democracies grant some level of religious group autonomy.

Several of these manifestations of religious group autonomy involve religious organisations being granted exemptions from various laws that might otherwise impinge on their freedom to control their internal structure. One common example is exemptions from laws governing employment relations-including prohibitions on (certain kinds of) discrimination in employment. In the UK, church ministers have traditionally been excluded from the ambit of various employment laws, either through being defined as 'office holders' or due to a lack of intent to create a legally valid contract. ${ }^{2}$ More recently, the Equality Act 2010 explicitly exempted 'organised religions' from elements of its non-discrimination requirements. ${ }^{3}$ Fairly uncontroversially, these provisions permit churches to discriminate on the basis of religion when choosing their leaders. But they also permit discrimination on other grounds, such as sex. Most prominently, the Catholic Church only permits men to be priests, and the same is true of various Protestant denominations, as well as Orthodox Judaism and many branches of Islam.

The European Court of Human Rights (ECtHR) has also developed a doctrine of religious group autonomy, viewing it as 'at the very heart of the protection which Article 9 [of the European Convention of Human Rights]

\footnotetext{
2 Julian Rivers, The Law of Organized Religions: Between Establishment and Secularism (Oxford, Oxford University Press, 2010), ch 4; Peter W. Edge, 'Judicial Crafting of a Ministerial Exception: The UK Experience' (2015) 4 Oxford Journal of Law and Religion 244. Courts now examine the specific facts closely to determine legal intent. On this basis, they have found such intent in some recent cases, but not in others. See New Testament Church of God v Stewart [2007] EWCA Civ 1004; President of the Methodist Conference v Preston [2013] UKSC 29; Sharpe v The Bishop of Worcester [2015] EWCA Civ 399.

3 Sch 9, paras 2-3.
} 
affords'. ${ }^{4}$ This includes the freedom to select, discipline, and dismiss members and leaders based on their own standards, and even justifies certain infringements on individuals' other Convention rights-and thus exemptions from the requirements that would otherwise apply. ${ }^{5}$

In the USA, the 'ministerial exception', affirmed by the Supreme Court in 2012, gives churches even greater autonomy within their ministerial employment decisions, which are deemed to be outside the purview of the state. ${ }^{6}$ The Court stated that 'requiring a church to accept or retain an unwanted minister... interferes with the internal governance of the church, depriving the church of control over the selection of those who will personify its beliefs'.7

Some liberal theorists have argued against these various kinds of corporate religious exemptions ${ }^{8}$, including in relation to church's employment decisions. ${ }^{9}$ Most, however, endorse some form of religious group autonomy that would permit some such exemptions. ${ }^{10}$ Some legal theo-

4 Hasan and Chaush v Bulgaria (2002) 34 EHRR 554, para 62.

5 See lan Leigh, 'Balancing Religious Autonomy and Other Human Rights under the European Convention' (2012) 1 Oxford Journal of Law and Religion 109; Pamela Slotte and Helge Årsheim, 'The Ministerial Exception-Comparative Perspectives' (2015) 4 Oxford Journal of Law and Religion 171, 179-194.

6 The question of who counts as a 'minister', and thus of the scope of the exception, is contested within the case law. See Carolyn Evans and Anna Hood, 'Religious Autonomy and Labour Law: A Comparison of the Jurisprudence of the United States and the European Court of Human Rights' (2012) 1 Oxford Journal of Law and Religion 81, 90-94.

7 Hosanna-Tabor Evangelical Lutheran Church and School vs. EEOC 565 U.S. ___ (2012), 3. See 15-20 for the Court's guidance on who counts as a minister.

8 Throughout, I use the term 'corporate exemptions' to refer to exemptions granted to religious groups qua groups. My focus is primarily on churches, but similar arguments would apply to other religious associations, charities, and so on. My discussion is also relevant to religious corporations, but that case raises various further issues that I do not have space to consider, so I do not have them in mind here.

9 eg, see Leslie C. Griffin, 'The Sins of Hosanna-Tabor' (2013) 88 Indiana Law Journal 981; Sarah Conly, 'In Defense of the (Somewhat More) Invasive State' (2016) 6 Philosophy \& Public Issues (New Series) 25, 35-6.

10 The kind of religious group autonomy that is endorsed by most liberal theorists, and that is my focus in this chapter, should be distinguished from claims of 'sphere sovereignty' or 'freedom of the church' that have risen to prominence in recent US legal literature, under the banner of 'religious institutionalism'. For this kind of view, see Richard W. Garnett, 'Do Churches Matter? Towards an Institutional Understanding of the Religion Clauses' (2008) 53 Villanova Law Review 273; Richard W. Garnett, 'The Freedom of the Church: (Toward) An Exposition, Translation, and Defense' in Micah Schwartzman, Chad Flanders, and Zoë Robinson (eds.), The Rise of Corporate Religious Liberty (New York, Oxford University Press, 2016). This view is trenchantly criticised in Richard Schragger and Micah Schwartzman, 'Against Religious Institutionalism' (2013) 99 Virginia Law Review 917. As 
rists focused on UK law have even argued that it ought to incorporate a narrow version of the US-style ministerial exception. ${ }^{11}$

The nature and scope of religious group autonomy has become increasingly controversial, however. In part, this is due to recent court decisions. The US Supreme Court has offered an expansive interpretation of the ministerial exception, and the ECtHR has permitted European states to side with church hierarchies in several recent employment disputes, even when other Convention rights were implicated. ${ }^{12}$ More generally, the growing reach of state regulation has made conflicts with religious groups' claims to autonomy increasingly common, and thus raised new questions about that autonomy's proper scope. ${ }^{13}$ These questions concern both the areas within which religious organisations should be granted exemptions and which organisations count as 'religious' in a way that makes them eligible for those exemptions.

The resolution of disputes over the scope of religious group autonomy depends upon its justification. Recent controversies have therefore led to a flurry of justifications being offered. Liberal justifications for group autonomy hold that the interests of individuals are its ultimate normative basis. Group autonomy is the conclusion of an argument that is grounded in individualistic normative premises. ${ }^{14}$ Various liberal justifications have been offered in the literature. All such accounts face a significant problem, however, which is that religious groups always contain dissenters-

they note ( $919 \mathrm{fn} 7$ ), proponents of religious group autonomy are not necessarily committed to the sovereignty of religious groups, the irreducibility of their moral status, or their distinctiveness compared to non-religious associations. This distinguishes the view from the stronger 'sphere sovereignty' account. For a response to Schragger and Schwartzman, defending the liberal credentials of the institutionalist view, see Paul Horwitz, 'Defending (Religious) Institutionalism' (2013) 99 Virginia Law Review 1049.

${ }^{11}$ eg Nicholas Hatzis, 'The Church-Clergy Relationship and Anti-Discrimination Law' (2013) 15 Ecclesiastical Law Journal 144; Edge, 'Judicial Crafting'.

12 Including, most recently, Fernández Martínez v Spain (2015) 60 EHRR 3; Travaš v Croatia App no 75581/13 (ECtHR, 4 October 2016); Károly Nagy v Hungary App no 56665/og (ECtHR Grand Chamber, 14 September 2017).

${ }^{13}$ For helpful discussion of the various reasons for the increased salience of this issue, see Paul Horwitz and Nelson Tebbe, 'Religious Institutionalism-Why Now?' in Micah Schwartzman, Chad Flanders, and Zoë Robinson (eds.), The Rise of Corporate Religious Liberty (New York, Oxford University Press, 2016).

${ }^{14}$ This is in contrast to some 'religious institutionalist' views. See Schragger and Schwartzman, 'Against Religious Institutionalism'. 
individuals who are members of the group but disagree with its current policies, doctrines, or structures. For example, these individuals might disagree with the group's current exercise of a corporate exemption. Or they might believe that they have been discriminated against in ways that ought to be legally redressed. Many of the cases that come to court involve (former) church employees who claim unfair dismissal, discrimination, or violation of some other right. If the focus is on the interests of individuals, then it is unclear how these internal dissenters' interests are promoted by the group being granted exemptions, or more generally enjoying an area of autonomy. ${ }^{15}$

This chapter explores this problem of internal dissenters, and ultimately seeks to defend corporate religious exemptions in the face of it, while remaining within the parameters of liberal theory. The chapter is structured as follows. First, I show in more detail why the presence of internal dissenters creates a problem for liberal justifications of corporate exemptions. I then consider three ways that liberal theorists might respond to the problem: appealing to religious groups' own decision-making procedures, to implied consent, and to exit rights. All of these arguments have some force, but none provide a fully satisfactory solution. Finally, I seek to develop my own solution, which builds on the insights contained in the various arguments we will encounter, but more directly confronts the problem by arguing that internal dissenters' own interest in freedom of religion can be promoted through religious groups enjoying a significant level of autonomy, including various corporate exemptions. My argument does not provide a full answer to questions regarding the scope of religious group autonomy, but it does offer some guidance. More importantly, it resolves a fundamental problem for liberal justifications of exemptions for religious groups.

\section{Liberal Justifications and the Problem of Internal Dissent}

15 Griffin's objections to the ministerial exception in 'The Sins of Hosanna-Tabor' centre on the harms that it permits to individuals. 
Liberal justifications for corporate exemptions appeal to the interests of individuals, and claim that those interests are best served, in certain contexts, by religious institutions being granted significant autonomy to control their own membership, structure, and ethos. Some of these arguments seek to justify exemptions by reference to rights held by individuals. Usually this involves appeal to rights of freedom of religion, freedom of association, or some combination of the two. For example, Richard Schragger and Micah Schwartzman argue that 'individual rights of conscience do all of the conceptual and normative work'. ${ }^{16}$ Thus, the ministerial exception 'is fully explainable as a defense of the freedom of conscience for individuals within the church'. ${ }^{17}$ Lawrence Sager, meanwhile, argues that individuals have a 'right of close association'-a right to be free from governmental intrusion into close and personal relationships. ${ }^{18}$ This includes the relationships among members of religious groups such as churches, and the relationships between individual members and their leaders. Religious groups should thus be permitted to discriminate in their decisions regarding membership and leadership. Imposing antidiscrimination legislation would violate individuals' rights of close association. Finally, Andrew Shorten argues that a combination of arguments appealing to individual rights to freedom of religion and of association give rise to religious institutions' (limited) right to direct their own affairs without interference. ${ }^{19}$

A different set of liberal arguments hold that religious institutions have distinctive rights qua institutions, which are ultimately grounded in individual interests, but are not simply aggregations of individual rights. For example, Mark Rosen argues that religious institutions aren't reducible

\footnotetext{
${ }^{16}$ Schragger and Schwartzman, 'Against Religious Institutionalism', 921.

${ }^{17}$ ibid, 975 .

${ }^{18}$ Lawrence Sager, 'Why Churches (and, Possibly, the Tarpon Bay Women's Blue Water Fishing Club) Can Discriminate' in Micah Schwartzman, Chad Flanders, and Zoë Robinson (eds.), The Rise of Corporate Religious Liberty (New York, Oxford University Press, 2016). For criticism, see Cécile Laborde, Liberalism's Religion (Cambridge, Mass., Harvard University Press, 2017), 59-61.

${ }^{19}$ Andrew Shorten, 'Accommodating Religious Institutions: Freedom Versus Domination?' (2017) 17 Ethnicities 252.
} 
to their members and are thus inadequately protected by an exclusive focus on individual rights. Some legitimate expressions of religious group autonomy cannot be plausibly construed as arising from individual conscience or associational rights. ${ }^{20}$ Nonetheless, Rosen holds that the appropriate protections for groups do derive from individual interests, as modelled in Rawls's original position. He argues that the parties in the original position would endorse a 'Religious Institution Principle' that bars the state from imposing rules that the religious community deems incompatible with adherents' developing and fully exercising the religion's conception of the good. ${ }^{21}$ Cécile Laborde, meanwhile, argues that religious groups can have two interests that justify certain corporate exemptions. ${ }^{22}$ 'Coherence interests' concern the group's ability to live by its own standards, purposes, and commitments by aligning its purpose, structure, and ethos. They are interests in sustaining group integrity. 'Competence interests' concern the group's distinctive ability to interpret it's own standards, purposes, and commitments. An association can permissibly discriminate in its membership and leadership when this reflects its central doctrine and mission and/or when it has special competence to judge the relevant criteria for the office. These two salient group interests arise from individuals' exercise of their freedom of association in forming and sustaining the group, so groups' rights to exemptions are derived from the liberal value of freedom of association.

These arguments, and others like them, seek to justify some kind of religious group autonomy, including certain corporate exemptions. The strength and scope of the protections that they afford to religious groups, including the scope of the kinds of groups that merit exemptions, varies between the different arguments. For example, Sager's argument only ex-

\footnotetext{
${ }^{20}$ Mark D. Rosen, 'Religious Institutions, Liberal States, and the Political Architecture of Overlapping Spheres' (2014) 2014 University of Illinois Law Review 737, 758-68, 782-4. Rosen criticises Schragger and Schwartzman, in particular. See also Rivers, The Law of Organized Religions, 318-22.

${ }^{21}$ Rosen, 'Religious Institutions', 768-84.

22 Laborde, Liberalism's Religion, 171-96. Importantly, for Laborde, it is not only religious groups that have these interests. What matters for Laborde is whether an association has the relevant interests, not whether it is a 'religious group'.
} 
tends to groups that can be plausibly viewed as enjoying 'close association', while Rosen's would include all institutions that a religion deems necessary for their adherents to flourish-which Rosen argues includes some educational institutions, and perhaps also some hospitals and even corporations. ${ }^{23}$ The different arguments are also vulnerable to different objections.

There is one crucial problem that confronts all such liberal arguments, however: religious groups are rarely, if ever, homogeneous. They almost always contain some individuals who oppose the group's current policies, including those relating to the exercise of an exemption. For example, some Catholics believe that the Church should ordain female priests-as some other Christian dominations with formerly male-only priesthoods have done (most notably the vast majority of provinces with the Anglican Communion, including the Episcopal Church in the United States and the Church of England). There are also many examples of ministers, and other employees of religious organisations, accusing their employers of various kinds of discrimination, challenging a decision to fire them, or disputing restrictions placed upon them by their church.

Liberal justifications for corporate exemptions seem to falter in the presence of this kind of internal dissent, since it is unclear how the dissenters' interests are served, or their rights protected, by the religious institution enjoying the exemption. ${ }^{24}$ For example, it is not obvious how a dissenter's close association rights are protected by her religious community being permitted to discriminate in ways that she considers objectionable. This is particularly evident in the case of Catholic women who want to be priests or individuals who believe they have been personally discriminated

\footnotetext{
${ }^{23}$ Rosen, 'Religious Institutions', pp. 775-7. For a more full-blooded defence of exemptions for various religious non-profit organisations, see Thomas C. Berg, 'Progressive Arguments for Religious Organizational Freedom: Reflections on the HHS Mandate' (2013) 21 Journal of Contemporary Legal Issues 279.

${ }^{24}$ Nahshon Perez, 'Why Tolerating Illiberal Groups Is Often Incoherent: On Internal Minorities, Liberty, 'Shared Understandings,' and Skepticism' (2010) 36 Social Theory and Practice 291 argues that internal dissent undermines many of the common liberal arguments for tolerating illiberal groups. My focus in this chapter is different from Perez's, but my arguments are relevant to his.
} 
against. Similar comments apply to dissenters' rights to religious freedom. With regard to Rosen's Religious Institution Principle, the presence of internal dissent raises the question of what it means for 'the religious community' to deem some rule incompatible with the exercise of the religious conception of the good. When there is disagreement about precisely that issue, it is unclear whether Rosen's principle can prohibit the imposition of the state's favoured rule. Finally, internal dissenters reject some of the group's apparent commitments and doctrines, which makes it less clear that it has a unified identity that could ground Laborde's exemptionjustifying coherence and competence interests.

The ECtHR has explicitly stated that religious group autonomy must be protected even in the face of internal dissent. ${ }^{25}$ I believe that this is correct. Religious groups should enjoy a significant degree of autonomy, including various corporate exemptions, even when they contain internal dissenters. But it is not clear how this view can be justified within existing liberal theories.

This is not a novel problem. Liberal theorists have long recognised that groups can both facilitate and restrict individual freedom. ${ }^{26}$ There are three obvious responses to the problem of internal dissent that liberal defenders of corporate exemptions can offer. First, religious groups have their own procedures for handling internal disagreements, and should be free to follow those procedures. Second, even dissenters have given implied consent to the group's own determinations of the contested issues. Third, internal dissenters are free to leave the group and form or join another group whose beliefs better align with their own. All three of these responses contain important insights. But all three also have significant weaknesses, which prevent them from providing a complete answer to the problem of internal dissent. In the following three sections I will consider these responses in turn, in order to highlight both their strengths and limitations. While I argue that they are insufficient to solve the problem of in-

\footnotetext{
${ }^{25}$ See Fernández Martínez, para 128.

${ }^{26}$ For a helpful summary, see Frederick Mark Gedicks, 'The Recurring Paradox of Groups in the Liberal State' (2010) 2010 Utah Law Review 47, 50-55.
} 
ternal dissenters, I do not mean to reject them completely; indeed, all three play a role within my own answer to the problem, which I present later in the chapter.

\section{Internal Decision-Making}

The first response is to hold that religious groups should be granted the freedom to resolve their internal disagreements in their own way, by following their own decision-making procedures when deciding on their policies. Indeed, for many this is precisely what religious group autonomy involves. This can be seen in the ECtHR's response to the issue of internal dissent: states 'should accept the right of [religious] communities to react, in accordance with their own rules and interests, to any dissent movements'. ${ }^{27}$ National authorities must not act as arbiters between group authorities and dissident factions. US courts have similarly been clear that proper regard for religious group autonomy requires respect for decisions made by groups' own duly constituted authorities and decision-making procedures. ${ }^{28}$ As the Supreme Court puts it, religious organisations' 'independence from secular control or manipulation' involves the 'power to decide for themselves, free from state interference, matters of church government as well as those of faith and doctrine'. ${ }^{29}$ Internal dissenters should thus voice their complaints to religious authorities, and campaign for change through the mechanisms provided by those procedures. Their success or failure at bringing about their desired reforms should depend on the operation of those procedures, rather than on state interference.

I think this position is largely correct, but it is not clear that the liberal accounts can justify it. Within the framework of the liberal justifications for exemptions, the argument for deferring to groups' own decisions only seems to have great force when those decisions are made using dem-

\footnotetext{
${ }^{27}$ Fernández Martínez, para 128.

${ }^{28}$ Christopher C. Lund, 'Free Exercise Reconceived: The Logic and Limits of HosannaTabor' (2014) 108 Northwestern University Law Review 1183, 1199.

${ }^{29}$ Kedroff v St Nicholas Cathedral 344 US 94 (1952), 116. The Court quoted this statement approvingly in Hosanna-Tabor, 11.
} 
ocratic procedures. The interests of individual group members will be adequately taken into account only if decisions are made democratically, so a concern for the interests of individuals will justify deference to the group's decisions only if democratic procedures are used.

This is clearest in Shorten's examination of groups' rights to institutional exemptions. ${ }^{30}$ Shorten argues that while it is religious institutions who are granted the legal right to an exemption, the moral right attaches instead to the group of individuals on whose behalf the institution acts. The normative justification for the exemption comes from those individuals' interests in freedom of religion and association. The gap between the legal and moral right can be bridged only if decision-making agents within the institution have legitimate normative authority to exercise the exemption, and this is the case only if those agents are authorised by the group to act on its behalf. It seems, however, that for this kind of authorisation to occur the members of the group either must all share the same view of how the exemption ought to be exercised or must democratically authorise the decision-agent and/or their decisions. ${ }^{31}$ The former condition obviously is not met in cases where there is internal dissent, so the latter condition-democratic decision-making-must be met if the exemption is to be justified.

Not all liberal justifications for corporate exemptions rely on as strict an account of authorisation as Shorten's. But his argument illustrates the more general point that it is not clear how deference to decisions made by non-democratic or hierarchical decision-making structures can protect the interests of ordinary group members, and especially the interests of those who disagree with the decisions that are made. This general point applies to all liberal accounts.

The reason that this is a problem, of course, is that many religious groups are internally hierarchical. While ordinary group members are free

\footnotetext{
$3^{\circ}$ Andrew Shorten, 'Are There Rights to Institutional Exemptions?' (2015) 46 Journal of Social Philosophy 242.

${ }^{31}$ This feature of Shorten's view is also noted by Jonathan Seglow, 'Religious Sovereignty and Group Exemptions' (2015) 44 Netherlands Journal of Legal Philosophy 231, 237 fn 12.
} 
to express their opinions, there is often little, if any, formal deliberation about the group's rules and structures, and decisions are made without democratic decision-making procedures such as voting. Further, decisions are often made not by individual congregations, but by centralised denominational authorities. Of course, this is not true for all religious groups. In some Protestant denominations important decisions are made democratically by individual churches. Other denominations incorporate representatives of the laity into their formal decision-making structures. But many church polities are hierarchical, such that corporate exemptions would not be justified if it were a condition for such exemptions that decisions were made democratically. The same applies to other religious institutions such as seminaries and religious schools. ${ }^{32}$

\section{Implied Consent}

A natural response at this point is to appeal to some notion of 'implied consent'. Those who join religious organisations implicitly grant authority over religious matters to the institution and its internal procedures. Even if those procedures are not democratic, such that individual members cannot be said to have directly authorised every decision made by the institution, each member has given implied consent to the decision-making procedures that are in place and thus to the decisions made by the group's duly constituted authorities. In Michael Helfand's words, 'religious institutionalism amounts to a constitutionally protected contract of sorts'.33 Helfand argues that religious group autonomy protects an agreement between the membership to have internal matters governed by religious law and doctrine. The US Supreme Court expressed this view in an important 1871 ruling:

All who unite themselves to [a religious association] do so with an implied consent to this government, and are bound to submit to it. But it would be a vain consent and would

\footnotetext{
${ }^{32}$ And, indeed, to non-religious institutions, such as universities.

33 Michael A. Helfand, 'Religious Institutionalism, Implied Consent, and the Value of Voluntarism' (2015) 88 Southern California Law Review 539, 570.
} 
lead to the total subversion of such religious bodies if anyone aggrieved by one of their decisions could appeal to the secular courts and have them reversed. ${ }^{34}$

The main problem with this argument is that in many cases it appears descriptively inaccurate. Many members of religious groups were inducted into those groups as children, and even those who join as adults rarely do so with full knowledge of all of the groups' doctrines, structures or decision-making procedures. It thus seems a stretch to hold that they have in some way consented to all of those things. And it is certainly implausible to view most individuals as giving consent to a fixed, monolithic set of beliefs, rules and hierarchies, since few religious groups are static or homogeneous in this way. The very problem of internal dissent arises precisely because religious communities are always sites of debate and contestation, in a way that makes it difficult to identify precisely what individuals can be said to have consented to. This is true even for groups' decision-making procedures and structures of authority; these matters are also often contested, and it is unclear that the majority of members can be said to have given consent to them simply through joining the group. These points are ably summarised by B. Jessie Hill, who has critiqued the implied consent argument at length:

In fact, religious membership is probably best understood not as a form of consent to a particular set of precepts or a particular dispute-resolution mechanism, but rather as membership in a dynamic community, whose contours are constantly subject to contestation. 35

This point should not be overstated. Many religious groups are hierarchical, and known to be so. But even for those groups, it is not really clear that individuals have given (implied) consent to all of the group's structures or decisions merely by being members. Indeed, this is true even

\footnotetext{
34 Watson v Jones 80 U.S. 679 (1871), 729.

35 B. Jessie Hill, 'Change, Dissent, and the Problem of Consent in Religious Organizations', in Micah Schwartzman, Chad Flanders, and Zoë Robinson (eds.), The Rise of Corporate Religious Liberty (New York, Oxford University Press, 2016), 426.
} 
for ministers and employees; their choice to be employed by the group does not necessarily imply consent to all of its structures and decisions.

Implied consent theory's descriptive inaccuracies do not necessarily undermine the underlying normative claim, however. Even if membership in a religious group is not experienced or viewed by members as a form of consent, this does not mean that consent is not the correct normative concept to apply. There is a parallel here to the way liberal theorists treat conceptions of the good more generally. Within liberal political theory, an individual's conception of the good is seen as chosen by her, and she is viewed as having the capacity to revise or abandon that conception. ${ }^{36}$ These claims are in one sense descriptively inaccurate. Many individuals experience their conception of the good as in some sense unchosen, and as a core component of their identity, such that abandoning that conception would fundamentally change who they are. They cannot (easily) stand back from, and reflectively revise, all of their ends in the way imagined within liberal theory. Even if all of this is true, however, it does not undermine the liberal theorist's claim that it is normatively appropriate to treat citizens as if their conception of the good is chosen, and to hold that their identity does not depend upon that conception, from the political perspective. This approach can lead to the correct political principles-for example, that changes in an individual's conception of the good do not affect her political rights and duties 37 -even if it is not an accurate reflection of most individuals' lived experience.

Something similar could be true for the implied consent argument in the context of religious group autonomy. Even if group members haven't actually given consent in any meaningful sense, it might be correct to treat them as if they did, and to use the idea of consent as a guiding normative principle, because this best captures the normative situation. ${ }^{8}$ But

\footnotetext{
${ }^{36}$ For example, see Rawls's explanation of the political conception of the person used within his political liberalism. John Rawls, Political Liberalism, expanded edn (New York, Columbia University Press, 2005), 29-35.

37 ibid, 30-1.

${ }^{38}$ Rawls makes this kind of argument about the authority of churches over their members. See John Rawls, Justice as Fairness: A Restatement (London, Harvard University
} 
this can only be the case if there are other reasons, which do not depend on consent, to respect group autonomy, and in particular groups' own decision-making procedures, even in the face of internal dissent. Appeal to the normative idea of implied consent must be shorthand for an argument that establishes that this is the right way to view the normative situation. This being the case, however, the normative heavy lifting must be done by that underlying argument, not by implied consent itself. 39 And that means that the notion of implied consent cannot do independent work in response to the problem of internal dissent. We need some other argument for corporate exemptions in the face of internal dissent, before we can use implied consent as a label for this conclusion. But that other argument is exactly what we are searching for.

One might think that one form of consent can do independent work, however. Even if members of a religious group do not consent to all of its beliefs, rules and authority structures by joining the group, perhaps they give implied consent by staying in the group. This brings us to the third response to the problem of internal dissent: an appeal to exit rights.

\section{Exit Rights}

A very common liberal response to dissenters within religious (and other) groups is to hold that they are free to leave the group, and to join or form another group whose beliefs or practices better fit with their own. The freedom to exit is the ultimate guarantee of each individual's freedom of religion and association. They are not forced to be members of a religious group, or to enjoy close association with people they disagree with. Even if the liberal state permits religious groups to govern themselves based on their own doctrines, including practising discrimination and imposing rules

Press, 2001), 93. For a fuller explication, see Schragger and Schwartzman, 'Against Religious Institutionalism', 958-62.

39 This is explicitly recognised by at least one of the theorists to whom Hill attributes the implied consent argument. Lund writes that implied consent might be a useful label to capture the normative situation, but is not doing the real normative work. 'Implied consent is a fiction used to operationalize the constitutional right of churches to have control over their own decisions' (Lund, 'Free Exercise Reconceived', 1200). The actual argument for that right must be found elsewhere. 
on members and employees, it will not allow any group to prevent individuals from leaving. Even the most ardent supporters of a strong form of religious group autonomy endorse this substantive limit upon it, due to its fundamental importance to protecting individual interests. $4^{\circ}$

As Christopher Lund puts this point:

An important aspect of church autonomy is how every insider has the right to leave, the right to become an outsider. Maybe this is part of the church autonomy principle itself; maybe it describes the limits of church autonomy. But either way, church autonomy implies a constitutional right of exit from religious organizations. ${ }^{41}$

Lund explicitly links a lack of exit, in the presence of exit rights, to a form of consent: 'People can leave or stay. But so long as they choose to stay, they accept how the church handles its religious affairs'..$^{2}$ The normatively salient kind of implied consent is given by staying within the group.

The ECtHR has also expressed this view: 'in the event of any doctrinal or organisational disagreement between a religious community and one of its members, the individual's freedom of religion is exercised by the option of freely leaving the community'. 43

Exit rights are certainly an important part of a satisfactory answer to the problem of internal dissent. ${ }^{4}$ But even this argument faces an important challenge, which is that it is not clear that freedom of exit is a sufficient protection for dissenting individuals' interests, in the light of the very arguments that justify religious group autonomy in the first place. Those arguments appeal to the great importance of religious institutions

\footnotetext{
$4^{\circ}$ Rosen, 'Religious Institutions', 787-8; Rivers, Law of Organized Religions, 336; Rex Ahdar and Ian Leigh, Religious Freedom in the Liberal State, 2nd edn (Oxford, Oxford University Press, 2013), 394.

${ }^{41}$ Lund, 'Free Exercise Reconceived', 1203

42 ibid, 1194.

43 Fernández Martínez, para 128. It is important to note that despite this strong statement, the ECtHR did consider Fernández Martínez's claim in detail, and sought to balance the infringement of his Article 8 rights against the Article 9 rights of the church. For discussion of this case, see Slotte and Årsheim, 'The Ministerial Exception', 186-193; lan Leigh, 'Reversibility, Proportionality, and Conflicting Rights: Fernández Martínez v Spain' in Stijn Smet and Eva Brems (eds.), When Human Rights Clash at the European Court of Human Rights: Conflict or Harmony? (Oxford, Oxford University Press, 2017).

44 I return to this point later-see pp. 23.
} 
to individuals. An individual's interest in pursuing a (religious) conception of the good can rarely be satisfied alone, since much of religion is about corporate activity. Rex Ahdar and Ian Leigh, for example, appeal directly to the importance of the group for the individual to justify group autonomy: 'If an individual's religious life is dependent on the vitality of the group to which the individual belongs then if follows that the religious group must have some independent autonomy of its own'. ${ }^{45}$ This thought is echoed by the ECtHR: 'Were the organisational life of the community not protected by Article 9 of the Convention, all other aspects of the individual's freedom of religion would become vulnerable'. ${ }^{46}$

Similarly, Rosen's justification for his Religious Institution Principle relies on the fact that parties in the original position would recognise the fundamental importance of religious institutions to many citizens' exercise of religion:

For many people, the freedom to develop and fully exercise a conception of the good requires that they be able to live in accordance with their religious convictions, which in turn presupposes the existence of certain religious institutions. The political structure chosen under the original position accordingly would be one that afforded such religious institutions special protections. ${ }^{47}$

A notable feature of these arguments is that they rely on the particular importance to individuals of existing and well-established institutions. This is true, explicitly or implicitly, in many liberal accounts of religious group autonomy. Most religious individuals exercise their freedom of religion and association through membership in a pre-existing group, and their interests are invested in that particular community.

In the light of this, exiting a religious group into which one has been inducted and socialised comes at a high cost, and this cost is hardly mitigated by the ability to join or establish some new group. Of course, individuals do move between religious groups, and some establish new

\footnotetext{
45 Ahdar and Leigh, Religious Freedom, 376.

${ }_{46}^{6}$ Hasan and Chaush, para 62; Fernández Martínez, para 127.

47 Rosen, 'Religious Institutions', 770-1.
} 
churches, denominations, and other religious organisations. But for most religious individuals, their interests are intertwined with a particular existing group, and the value that this group gives is to a significant extent nonfungible. $4^{8}$ Leaving would be costly to their interests. And this can be true for internal dissenters, just as much as for those who are in complete agreement with their group's doctrines and structures. Further, it might be especially true for ministers, and other employees. Their livelihood depends upon the group, and they are unlikely to be happy simply to find employment in some other denomination, given their likely theological and pastoral commitment to their current denomination.

The very premises concerning the relationship between individuals' interests and religious group autonomy that justify corporate exemptions seem to make the freedom of exit response to internal dissenters insufficient. Exit rights will certainly be a necessary feature of an adequate response, as I discuss below. But they cannot work alone.

\section{Justifying Deference to Religious Groups' Procedures}

One response to my arguments thus far would be to conclude that religious groups should only be granted corporate exemptions when they are internally democratic. We have reason to respect such groups' decisions, since their decision-making procedures acknowledge and incorporate the interests of all group members, and the group can be said to have authorised the resulting decisions. When this is not the case, corporate exemptions should not be granted.

I think that this would be too restrictive, however. It would certainly be more restrictive than the present policies across Western liberal democracies, and than the positions defended by many theorists. One implication, for example, would be that the Catholic Church would no longer be permitted to have a male-only priesthood. While some theorists have de-

\footnotetext{
$4^{8}$ Hill, 'Change, Dissent', 426-7, makes a similar point. I should note, however, that I disagree with some of her claims and with the implications that she draws from the argument.
} 
fended this conclusion, 49 I think that the majority are right to hold, in line with current legal practice, that hierarchical religious groups should be eligible for exemptions. The question is whether this can be defended on liberal grounds, despite the presence of internal dissent, or whether one would need to look beyond the limits of liberal political theory in order to justify this position.

The key to providing a liberal justification is to argue that we have good reasons to defer to religious groups' own decision-making procedures on matters of their internal structure and policies, even when this involves decisions being made by a small group of elites within the group, and even when some members strongly disagree with those decisions. In other words, we need an argument that we have good reasons to defer to religious groups' means of reaching judgements, as well as to those judgements themselves. The question is what those reasons could be, if appeal to implied consent and exit rights are insufficient, as I have argued.

While some theorists seem to overlook this issue, and seem to premise their arguments on an unrealistic degree of internal homogeneity within religious groups, or to simply take groups' decisions as given, others have explicitly pointed in the right direction. For example, Rosen claims that his Religious Institution Principle should be interpreted as allowing groups' policies to be set by their leaders. He argues that

what matters is the perspective of the religion's formal leaders, not its lay members. The principle presupposes the continued existence of necessary religious institutions, and religious institutions can survive only if the formal leaders' understandings of the institution's requirements are determinative..$^{0}$

This argument is unpersuasive, however. It is not clear why the survival of a religious institution would depend on the current leaders' perspectives being followed. Certainly, the institution would change if the

\footnotetext{
49 eg Conly, 'In Defense', 35-6.

50 Rosen, 'Religious Institutions', 773. Rosen notes that this holds only if all members enjoy substantive freedom of exit.
} 
leaders' judgements were not determinative. But this does not mean that it would cease to exist. Further, the changes might be in the interests of some group members, and particularly those of internal dissenters. Rosen seemingly fails to consider the perspective of these internal dissenters. Yet parties in the original position would take their interests into account, and it is thus not obvious that a principle chosen in the original position would grant group leaders the level of authority that Rosen suggests.

More promisingly, Laborde argues that religious groups have 'competence interests' that justify a level of judicial deference when it comes to decisions that involve interpreting the group's own standards and commitments. ${ }^{51}$ Religious groups' decisions about their structures and policies are based on their theological beliefs and doctrines. The Catholic policy regarding the priesthood, for example, is based on an understanding of the role of the priest as representing Jesus and a doctrine of apostolic succession, both of which rule out female priests. Dissenters to that policy similarly base their opposition on theological arguments. The state is not in a position to adjudicate the merits of the relevant theological claims; it lacks competence. The religious group has an interest in making these judgements based on its own standards-an interest in deciding for itself what is required in order for it to pursue its purposes and commitments, and thus to serve it's 'coherence interests'. The state, meanwhile, lacks the ability to assess those standards.

Courts have recognised these limits to their competence. The ECtHR has emphasised that states must not determine the legitimacy of religious beliefs or the means used to express them, including decisions regarding structure, employment, and so on. ${ }^{52}$ It has thus refrained from taking sides in intra-religious disputes and from judging the substantive merits of the (religious) reasons underlying religious groups' decisions.53 US courts have gone even further, holding that state interference in reli-

\footnotetext{
${ }^{51}$ Laborde, Liberalism's Religion, 190-6.

${ }^{2}$ Hasan and Chaush, para 78; Fernández Martínez, para 128.

53 Leigh, 'Balancing Religious Autonomy', 114-6; Evans and Hood, 'Religious Autonomy', 94-9.
} 
gious institutions' decisions about internal governance would amount to an establishment of religion. ${ }^{54}$ In the context of the ministerial exception, the Supreme Court's ruling in Hosanna-Tabor states that 'According the state the power to determine which individuals will minister to the faithful also violates the Establishment Clause, which prohibits government involvement in such ecclesiastical decisions. ${ }^{55}$

Once again, there is something importantly right about Laborde's argument. But it is still not clear that it is sufficient to justify deference to the religious institutions' own decision-making procedures in the presence of internal dissent. In particular, a critic could ask why the state should prioritise religious groups' competence interests in the face of complaints by internal dissenters who believe both that the group has got its religious judgements wrong and that they have been unjustly treated or discriminated against. Given the conflict of interest between the group authorities and dissenting individuals, it is not clear that the competence interest of the former are sufficient to justify a prohibition on the state from acting on behalf of the later.

So are further arguments available that explicitly defend group autonomy in the face of internal dissent? I think that there are, and will develop my own account in the next section. This account draws upon several of the arguments we have already encountered but includes crucial further elements that provide a stronger grounding for internally contested corporate exemptions.

\section{Group Autonomy in the Face of Internal Dissent}

The key to solving the problem of internal dissent is to recognise that even dissenters can be exercising their religious freedom by being part of the

\footnotetext{
54 It is worth noting that there are important differences between the ECtHR and US courts with regard to their level of abstention from examining religious groups' decisions. See Evans and Hood, 'Religious Autonomy'. These differences are not directly relevant to my argument here, but I explore them in my 'The Scope of Religious Group Autonomy: Varieties of Judicial Examination of Church Employment Decisions' (working paper).

55 Hosanna-Tabor, p. 14. ('Also' because the court had just noted that the Free Exercise Clause would be violated.)
} 
group, and thus their religious freedom, as well as that of other group members, is protected by the state's non-interference. The religious freedom of all individuals, including the dissenters, is dependent on groups being given a certain level of autonomy. I take it that this is the idea that Ahdar and Leigh, Rosen, and the ECtHR are pointing toward, but it requires further explication if it is to justify their conclusions.

Internal dissenters believe that their religious group's current rules or structures are wrong, and want to see them changed. In the extreme cases that come to court, the dissenter believes that a particular decision made by the group was unjust or wrongfully discriminatory, and should be overturned by the state. In this sense, therefore, they believe that their interests are not adequately taken into account by the group, and that protection for those interests requires changes to the group's decisions or structures.

Nonetheless, respect for religious group autonomy protects the religious freedom even of these individuals, because that respect is what ensures that all individuals can unite around and practice particular religious conceptions. If the law sides with dissenters then this freedom will be liable to be overruled whenever there is internal dissent. Even if the individual's particular interest in (not) being treated in a certain way by the group seems to be ill-served by group autonomy in the specific case at hand, her broader interest in the freedom to form and pursue her own religious conception is protected. Everyone benefits from group autonomy, in this sense, even if some also bear costs.

Up to now I have presented the problem of internal dissent as a conflict of interests, with the group on one side and the dissenter on the other. The arguments for group autonomy that I have considered each try to show that the group's interest is overriding, or that the strength of the dissenter's interest should be given lesser weight-on account of her implied consent or exit rights, for example. ${ }^{56}$ My central point in the previous

${ }^{56}$ Ahdar and Leigh, Religious Freedom, 391-4, explicitly present the issue in this way. 
sections was that these arguments do not seem to give adequate weight to the dissenter's interests.

My point here is that we can instead hold that everyone has interests on the side of group autonomy, even if dissenters might also have interests on the other side. We are not simply weighing the interests of the group against those of the individual; we are weighing the individual's own interest in religious freedom, along with that of the other members of the group, against her interest in a particular form of treatment in the specific case at hand. It is the fact that the dissenter also has interests on the group autonomy side of the equation that can justify granting that autonomy.

Lund argues that religious group autonomy protects everyone's freedom to practice their own understanding of the faith, because it prevents individuals from using the law to control others' religious choices. 'Dissenters do not get to control their churches through litigation',57 because this would involve them imposing their religious views through law. In cases implicating the ministerial exception, for example, the fired minister is in effect claiming a right to force the religious group to accept him as a minister-'to practice religion with them, no matter what they want'..$^{8}$ 'Insiders should not be able to bring suits that impinge on a church's chosen religious beliefs or practices', 59 because this would allow them to force their version of the faith on others.

The extra emphasis that needs to be added to Lund's argument here is that not allowing dissenters to shape the group via litigation protects the religious freedom even of those who are seeking to do the shaping. This is not only a case of protecting the group's religious freedom against the claims of dissenters; it also about protecting the religious freedom of the dissenters themselves. It protects their general interest in not being forced to practice their religion in ways that they reject or with people they do not wish to, and in not having others' understanding of the religion imposed upon them, since today's dissenters might well become

57 Lund, 'Free Exercise Reconceived', 1199.

58 ibid.

59 ibid, 1215. 
tomorrow's defenders of orthodoxy. If dissenters can shape the group through litigation, then today's dissenters are at risk of having tomorrow's dissenters' version of the faith imposed upon them.

A critic might respond by arguing that the dissenters are already having others' understanding of the religion imposed upon them; in the particular case at hand, the group is enforcing a view that they reject. And this is true in a sense. But not in the same sense that would be involved in the state enforcing a particular understanding through law. The dissenter is forced by the group's internal decision-making procedures, along with their membership in the group. But this is different in kind to being forced through legal sanctions. The latter leaves the group with no choice but to comply with the view of the dissenter, since the state can enforce that view through financial and other penalties. Whereas the dissenter does continue to have other options, including both exercising her voice to seek to bring about change through the group's decision-making structures, and leaving the group.

This last comment brings us back to exit rights. I argued above that appeal to exit rights was not sufficient to justify legal deference to the group's internal decision-making. But the dissenter's freedom to leave the group and form or join a different one is still crucial, since it is the ultimate guarantee of their freedom from being forced to practice religion with people they do not want to. In order to be such a guarantee, exit rights must be substantive, or meaningful, and not merely formal. ${ }^{60}$ As well as formal legal protections from being coercively constrained to remain in the group, adequate knowledge of other groups must be available, and individuals must have sufficient education and opportunities (including employment opportunities) to leave the group without facing great material loss. ${ }^{61}$ If an employee of a religious organisation had no job prospects

\footnotetext{
${ }^{60}$ All defenders of religious group autonomy acknowledge this point. eg Rosen, Religious Institutions', 788-9; Ahdar and Leigh, Religious Freedom, 394. But there is scope for disagreement about exactly what it requires. My comments here are necessarily brief, leaving many questions of specifics unanswered.

${ }^{61}$ Jeff Spinner-Halev, 'Liberalism and Religion: Against Congruence' (2008) 9 Theoretical Inquiries in Law 553, 568-71.
} 
outside of the group then this would severely weaken the group's autonomy claims, and in some cases might even justify forcing the group to keep the employee against its wishes. More generally, ensuring substantive exit rights might at times involve a certain level of interference with religious groups, since it imposes informational and educational requirements that some might consider objectionable. This level of interference is necessary in order to guarantee the religious freedom of all, however.

Even substantive exit rights do not mean that leaving a religious group is easy. Indeed, it might still carry a great psychological cost, as I have already noted. Nonetheless, such rights are sufficient to ensure that dissenters are not forced to remain members of religious groups in the way that state intervention would force groups to change their policies.

Further, as Jeff Spinner-Halev comments, 'liberalism does not... have to make leaving one's community psychologically easy... People in liberal societies are often confronted with all kinds of tragic choices, to which liberal theory has few answers'. ${ }^{62}$ The requirement of liberalism is to ensure that everyone's freedom of religion is protected, and while this requires substantive exit rights, it does not require removing all psychological costs. This does not mean that those costs are irrelevant or can simply be ignored. As I argued above, they show that an appeal to exit rights cannot carry the full justificatory burden in an argument for religious group autonomy. Instead, my argument here is that the balance of interests involved in granting religious group autonomy, constrained by substantive exit rights, is justified overall, in the light of the fact that group autonomy protects the religious freedom of all individuals, including dissenters themselves.

We should also note here that many thousands of individuals in liberal democracies have left religious groups, joined alternative groups, and indeed started new groups and denominations. Exercising the option of exit is rarely easy or costless, but it is still something that many have done.

\footnotetext{
62 ibid, 571-2.
} 
Liberal democracies have proven to be fertile ground for a great diversity of religious groups, organisations, and denominations to emerge.

As well as the option of leaving the group, dissenters can also seek to change the group from within. Indeed, adequate protection for the interests of dissenters requires that religious groups have internal mechanisms through which individuals can express dissent and seek to convince others of their diverging views. Groups with no tolerance for dissenters thus have weaker autonomy claims. This does not mean that groups must be nonhierarchical or democratic, however. Even hierarchical groups almost always contain avenues for discussion and reform. Dissenters often exercise their religious freedom by acquiescing to policies that they object to, while at the same time campaigning for their reform, through both formal and informal channels.

Indeed, the fluid and dynamic nature of religious communities that Hill appeals to in her objections to implied consent as a grounding for religious group autonomy can actually provide further support for such autonomy. Hill argues that the pervasiveness of change and contestation within religious groups means that it is not always easy to identify with certainty their doctrinal beliefs or authority structures. It even 'may not always be possible to determine who is a dissenter and who represents the church itself'.63 I think Hill somewhat exaggerates her point here. Nonetheless, her basic thought actually supports group autonomy by highlighting the fact that there is space for internal conflict and change within most religious groups. Hill claims that her arguments undermine religious group autonomy, because it is hard to appeal to the church's right 'to keep its beliefs pure against the influence of dissenters ${ }^{\prime 64}$ when it is difficult to say precisely who is 'the church'. But group autonomy was never about 'purity', or about protecting or reifying any particular policies or structures. It is about allowing disputes to be settled by the group itself, by whatever processes members collectively come to recognise as valid, free from state

\footnotetext{
63 Hill, 'Change, Dissent', 431.

64 ibid.
} 
interference. The fluidity of groups' doctrines and structures actually bolsters the claim that all members, including dissenters (whether we can identify them or not), can have the exercise of their religious liberty protected by group autonomy. It thus supports the view, expressed by both the ECtHR and US Supreme Court, that states should not act as arbiters within internal disputes.

Hill's argument also points us back to Laborde's notion of 'competence interests'. Religious groups have an interest in working through the complexities that Hill highlights to form their policies and judgements based on their own understandings and processes, and the state lacks the competence to pass judgement on the results. Again, the religious freedom of all individuals, including internal dissenters, is protected by the state respecting religious groups' distinctive competence.

\section{Internal Dissenters or Liberal Congruence?}

Up to now I have assumed that the liberal concern is for 'internal dissenters'-individuals within religious groups who disagree with their policies or structures. The reply to this concern is that even internal dissenters can be exercising their religious freedom by being part of the group, and if the law regularly sides with the individual then it means there is no way to protect collective freedom to unite around religious conceptions, since this freedom will be overruled whenever there is internal dissent.

But perhaps the assumption that the concern is with all internal dissenters is mistaken. After all, internal dissenters are just as likely to be conservative as progressive. They can be individuals who believe that the group has strayed from traditional doctrine, and want to reassert old orthodoxies. For example, Reverend Paul Williamson brought a series of lawsuits in an attempt to prevent the ordination of women by the Church of England-including appealing to the ECtHR, claiming that his Article 9 right to freedom of religion had been violated. ${ }^{65}$ According to Williamson,

65 Williamson v UK App no 27008/95 (ECtHR, 17 May 1995). His claim was dismissed as inadmissible. 
the ordination of women fundamentally changed the nature of the Church of England without his consent, requiring him to accept a policy that violates his religious conscience, and leaves him faced with constructive dismissal for not agreeing with the measure.

Liberals, or at least liberal egalitarians, are unlikely to have much sympathy for dissenters like Williamson. They would presumably deny that he has legitimate interests at stake in preventing female ordination, and hold that he is owed no compensation if he resigns from his post in protest. Perhaps this suggests that the liberal concern is not in fact for internal dissenters per se, but only for those individuals whose interests are set back by decisions that are incongruent with certain substantive liberal valves, such as equality and non-discrimination. This would include women in the Catholic Church and those who are denied membership or employment within a religious group on discriminatory grounds. These individuals have their interests substantively neglected in a way that Williamson does not. Perhaps, therefore, the state should intervene on behalf of those individuals, and not grant corporate exemptions in those cases.

This kind of approach seems to be suggested by Jonathan Seglow, who argues that exemptions for religious groups might be permissible only if those in control of an association find their beliefs significantly burdened by a law, ordinary members of the group have in some sense consented to their control, and the proposed exemption will not set back the interests of ordinary members. ${ }^{66}$ Seglow notes that this will not justify exemptions permitting discriminatory practices, since these will not be in members' interests. In other words, within Seglow's account, an independent judgement of what is in individuals' interests is what determines whether exemptions can be granted, rather than a concern with internal dissenters perse.

The upshot of this, however, is that the argument no longer concerns internal dissenters at all. Male-only priesthood would be ruled out even if no members of the group objected to it. The argument instead is

\footnotetext{
${ }^{66}$ Seglow, 'Religious Sovereignty', 238.
} 
simply about enforcing liberal egalitarian values upon religious groups who believe that they have religious or moral reasons to deviate from those values within their associational life. In effect, this approach holds that it is impermissible for individuals to form groups on the basis of non-liberal beliefs or practices. In other words, it endorses the 'logic of congruence', ${ }^{67}$ according to which all civil society groups must be structured in accordance with the same values and principles that inform the liberal democratic state. Some advocates of religious group autonomy have expressed concern that the law might be heading in this direction. ${ }^{68}$

I do not have space to consider this view in detail. The key point for our purposes is that this argument is distinct from the internal dissenters objection, so cannot function as a direct reply to my argument for religious group autonomy in the face of internal dissent. Instead, it shifts the ground to a different debate. Further, many theorists have argued against the logic of congruence, arguing that individuals should be free to form groups whose internal rules and procedures do not replicate the principles that ought to govern the liberal democratic state. ${ }^{69}$ While I cannot offer a full defence of this claim, I think that the arguments in favour of religious group autonomy and corporate exemptions apply even when the group's beliefs and practices run counter to liberal egalitarian ideals. Religious groups have rights to structure their affairs-including their decisions on membership and leadership-on the basis of their own beliefs and doctrines, even when this means discriminating in ways that would be impermissible for the state. These rights are grounded in the interests of individvals in freedom of religion and association-including the interests of those who are discriminated against by a particular group.

\footnotetext{
${ }^{67}$ This term comes from Nancy Rosenblum. For a recent articulation, see Nancy L. Rosenblum, 'Faith in America: Political Theory's Logic of Autonomy and Logic of Congruence' in Alan Wolfe and Ira Katznelson (eds.), Religion and Democracy in the United States: Danger or Opportunity? (Princeton, NJ, Princeton University Press, 2010).

68 eg Rivers, Law of Organized Religion, 146, 321, 333-4.

69 For recent critique, see Jacob T. Levy, Rationalism, Pluralism, and Freedom (Oxford, Oxford University Press, 2015), 51-5; Ahdar and Leigh, Religious Freedom, 389-91. See also my 'Shaping Religion: The Limits of Transformative Liberalism' (working paper).
} 
Indeed, if this argument for religious group autonomy is correct, then it suggests that groups' freedom to select their own members and leaders according to their own principles and procedures perhaps should not be seen as an exemption, but as itself being the rule. In the UK context, Rivers argues that the values at stake should be conceived not as an 'exception to a higher principle of non-discrimination', but as a question of whether there should be exceptions to the 'right of collective religious liberty'. ${ }^{70}$ Lund makes a similar point in the US context, noting that the Supreme Court opinion in Hosanna-Tabor does not really conceive of the ministerial exception as an exemption:

The Court does not ask whether churches should be exempt from employment discrimination laws. Instead, the Court asks whether churches have the right to choose their leaders. This is more than a clever rhetorical flourish-it a change in baseline. ${ }^{11}$

This is not to say that churches have complete jurisdictional authority, or enjoy a kind of 'sphere sovereignty' that prevents any kind of government regulation. The kind of religious group autonomy that I have discussed, and defended, falls short of 'sphere sovereignty'. ${ }^{22}$ There are clear cases where a concern for the interests of individuals will mean penalising groups-such as when group members or leaders have been subject to sexual harassment or physical abuse, ${ }^{73}$ or when groups have not adequately protected exit rights. My argument for religious group autonomy depends on balancing the interests of individuals, and this balancing leads to a robust but not absolute form of autonomy.

The precise kinds of government examination of, and intervention in, groups' decisions that are deemed (un)acceptable will depend on further details of the argument and of specific cases. I lack space to explore

\footnotetext{
70 Rivers, Law of Organized Religions, 136.

${ }^{71}$ Lund, 'Free Exercise Reconceived', 1192.

${ }^{72}$ See $\mathrm{n}$ 10, above. Many of the other theorists I have discussed, including Rosen, Rivers, and Laborde, also explicitly distinguish their views from the 'sphere sovereignty' account. 73 For discussion of such cases, see Lund, 'Free Exercise Reconceived', 1217-20; Laycock, 'Church Autonomy Revisited', 268-78.
} 
these detailed implications here, but believe that my account would justify many of the protections of religious group autonomy afforded in today's liberal democracies. I hope to have shown that such autonomy can be justified within liberal theory even in the face of internal dissent, through an appreciation of the way in which it protects the interests of all individuals, including dissenters themselves. ${ }^{74}$

${ }^{74}$ I owe thanks to John Adenitire for helpful comments on earlier drafts of this chapter. 